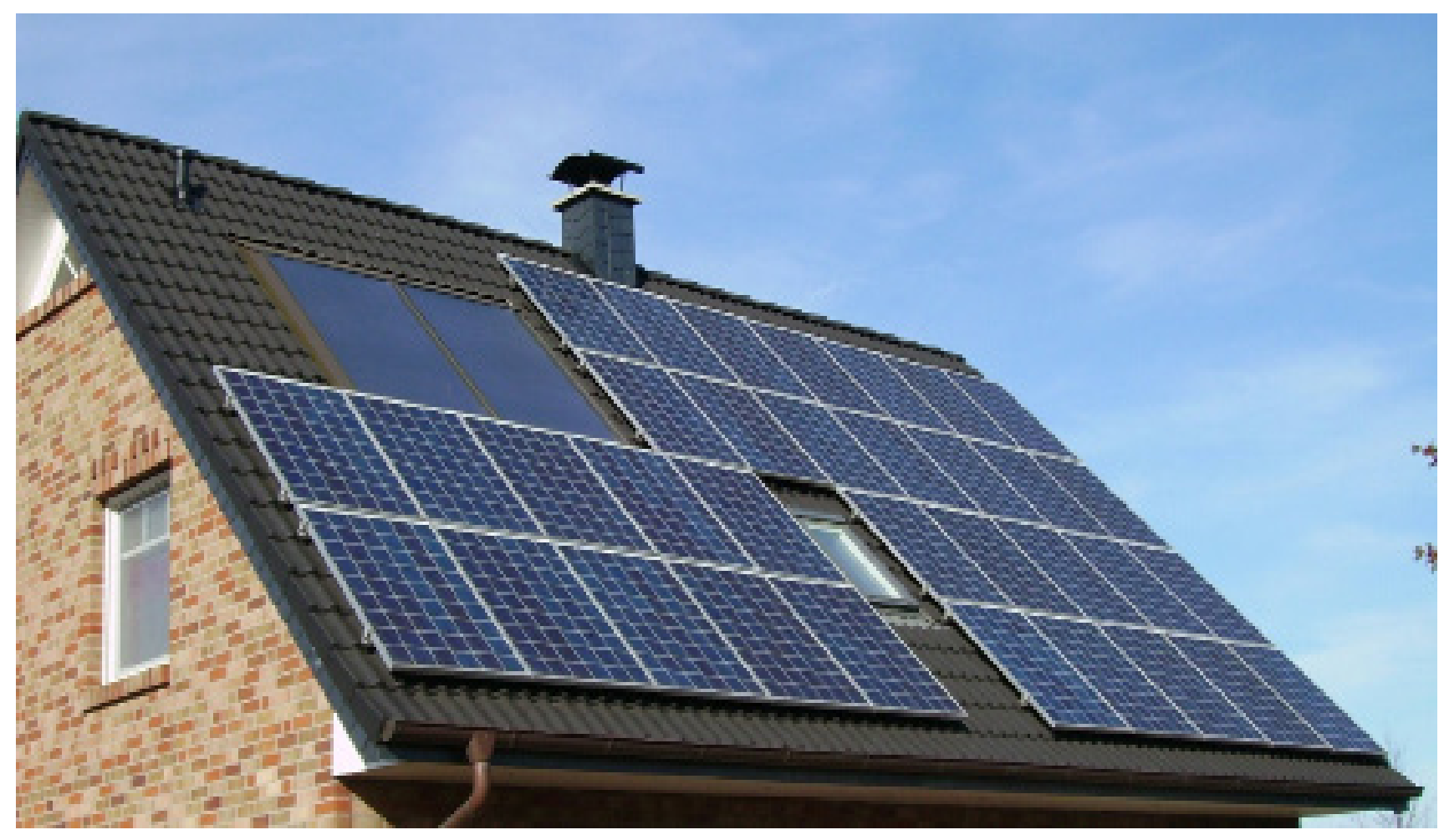

\title{
Environmental sustainable processes in construction of buildings in Cúcuta
}

\section{Procesos ambientalmente sostenibles en la construcción de edificios en Cúcuta}

Lucero Moncada-Ortiz

Estudiante de Ingeniería Civil, lucerodelpilarmo@ufps.edu.co,

https://orcid.org/0000-0003-2145-3677, Universidad Francisco de Paula

Santander, Cúcuta, Colombia 
Recibido: Febrero 11 de 2019
Aceptado: Mayo 16 de 2019

Cómo citar: L. Moncada- Ortíz, "Environmental sustainable processes in construction of buildings in Cúcuta", Sostenibilidad, Tecnología y Humanismo, vol. 10, no. 2, 56-64, 2019.

\section{Abstract}

The present article describes the problem that is presented in the city of Cúcuta, by means of the contamination to the environment that is generated by the constructions of buildings, through the constructive process of the conventional model that this implemented until the present time, an optimal strategy was evaluated to diminish the environmental impact by the constructions, a more friendly process with the environment that is being implemented in other countries and even at national level, as it is the environmental sustainable processes in the construction of buildings.

Keywords: environmental pollution, problems, construction process, environmental sustainable processes, traditional construction raw, material sustainable, urban development housing infrastructure, solid waste.

\section{Resumen}

El presente artículo describe el problema que se presenta en la ciudad de Cúcuta, mediante la contaminación al medio ambiente que se genera por las construcciones de edificios, a través del proceso constructivo del modelo convencional que esta implementado hasta el presente, se evaluó una estrategia óptima para disminuir el impacto ambiental por las construcciones, un proceso más amigable con el medio ambiente que se está implementando en otros países e incluso a nivel nacional, como es el proceso de sostenibilidad ambiental en la construcción de edificios.

Palabras clave: contaminación ambiental, problemas, proceso de construcción, procesos ambientalmente sostenibles, materia prima de construcción tradicional, desarrollo urbano sostenible, infraestructura de vivienda, residuos sólidos. 


\section{8}

Introduction

In different places of the world they are taking into account some sustainable processes for civil constructions, due to the great environmental impact, to be able to give value to the environment it is necessary to know diverse processes to protect the surroundings, a very special case is in Spain that they implement the green constructions consists of making sustainable buildings that are better than the current buildings, costing less to construct and to maintain. Today, most countries, including world powers, already have such alternatives and have implemented them when it comes to constructing buildings that benefit all inhabitants. The construction of sustainable processes aims conceptually to rationalize, save, conserve and improve the way it is built conventionally.

Due to the uncontrolled population growth, a considerable increase has been seen in the construction sector, which requires a great demand for natural resources, the exponential increase of waste and pollutants that generate greenhouse gases, bringing with it great pollution to the environment. In order to preserve the environment, it is necessary to build healthier buildings, innovating the way they are built today, applying sustainable, viable and environmentally friendly processes and thus reducing the deterioration of our habitat [1].

By applying these processes in the construction sector, it would bring great benefits such as the rational consumption of energy and water in an efficient manner throughout its life cycle, the use of materials that are not harmful to the environment, resulting in comfort and health. The use of materials with low toxic emissions, this was carried out for the maintenance of the interior of a healthy environment, this is related to the needs of the occupant, safety, noise reduction and pollution [2]; accordingly, authors such as [3] point out that waste industrial materials can be used for the manufacture of building materials, reducing pollution and improving certain technological properties of these materials.

Another clear example of sustainable construction in the world can be seen in one of the most powerful and influential countries as it is the United States, since there is one of the most fascinating works as it is the great green ring (Apple Park) in California, not only highlighted by its immense size, but by the sustainable techniques implemented environmentally friendly, one of many features that we can highlight in this building is its natural ventilation at $100 \%$, considered worldwide as the building with more natural ventilation in the world thus avoiding the use of air conditioning or heating. There are so many features that can surprise mankind and other countries in the world by combining innovation and technology with sustainable construction techniques seeking benefits for the conservation of the environment that it cannot be overlooked that the Apple Park is covered by curved glass panels in its entirety making it one of the largest solar energy facilities on the planet. [4].

Similarly, in Peru, they are making incursions into sustainable practices in building construction, which are oriented towards minimizing the environmental, social, and economic impacts related to this model of construction. Peru is currently experiencing a boom in the construction sector due to the economic process that is now underway. Therefore, sustainable practices are proposed for the life cycle of a construction project that are oriented towards mitigating the negative impacts that the construction of traditional buildings entails. In a wider context it is intended to publicize the concept of sustainable engineering in the area of construction of the country, and taking into account that the decisions taken not only emphasize the economic sphere, but 
to consider other areas that are fundamental as it is the social and environmental, this has been seen largely to increase awareness of the environment, industries are assessing how their different activities and processes affect the environment, in which society has begun to worry about the problems of natural resource depletion and environmental degradation. [5]. As is also evident in Colombia due to the demand for sustainable processes in the construction of buildings were seen in the obligation to implement some processes, giving rise to high performance projects and comprehensive sustainability to mitigate climate change, ensure the welfare of the population and most importantly the care of the environment. The sustainable development does not imply limits, but if limitations on the part of the technology, the capacity of the biosphere to absorb the effects of the activities of the man, imposes the resources of the environment. [6] Choosing to improve the quality of life does not only mean living well, but also taking care of mother earth in order to live in satisfaction.

At the departmental level, Colombia has made great progress in recent years in terms of public policy, incentives and private sector commitments for the development of sustainable projects. We can take as an example Cundinamarca, Antioquia, Quindío and Cauca which are the ones that lead the list of sustainable projects presented at present in the certification process(leed y edge). These are buildings that help transform the construction sector with respect to ecosystem growth, reduction of environmental impact and compliance with the goals of the Paris agreement in terms of reducing greenhouse gases and improving the quality of urban life [7].

Therefore, in the city of Cúcuta, it is essential to carry out different proposals in terms of the construction sector for more environmentally friendly construction models, an example of which are the environmentally sustainable processes in building construction. In order to improve the environment, it is very necessary that construction companies become more involved in this construction model, taking it as a basis for all their projects, bearing in mind that Cúcuta has adequate characteristics both for the extraction of materials to be implemented, and for the execution of their respective projects in different locations or areas of the city. Therefore, Cúcuta, having a large amount of raw material such as clay, does not see the need to bring in materials from other regions. In this way, it should create sustainable alternatives due to the great environmental, social and economic impact that it has as a border region. [8].

\section{Objetives}

\section{Overall objective}

- To analyze an optimal strategy that allows to minimize the environmental impact that is generated by the constructions of buildings of traditional way, and thus to allow to diminish the negative effects that produce on the ecosystem, in which they cause a direct and indirect contamination.

\section{Specific Objectives}

- To know and analyze the conditions of the materials that are being used in sustainable constructions.

- Describe the environmental contribution, which is obtained with the implementation of sustainable processes in building construction.

- Identify the differences in the execution of a sustainable construction to a traditional one. 


\section{0}

Justification

The aim is to analyse why it is important to build buildings using environmentally sustainable processes in Cúcuta, in order to offer builders and designers a perspective on building construction that differs from traditional ones, in which it promises a number of environmental and economic benefits.

It is an interesting and necessary opportunity to reduce the harmful effects that we cause to the environment, promoting the change of constructive paradigms, innovating the way in which it is constructed at the present time, entering into technological products more friendly with the environment. This model of construction helps to reduce the high rates of energy consumption and exploitation of natural resources.

In conclusion, the proposal of environmental sustainability in constructions, allows that the criteria of City, buildings and community are interlaced each one with a transcendental contribution for the conformation of a collective good, of which we will diminish the negative effects of the constructions that are made traditionally and thus to contribute a better environmental ecological future to the new generations.

Theoretical frame

\section{Background:}

In the same way, research has been carried out such as that presented by [9] conducted research on environmental sustainable construction, an alternative for the construction of social and priority housing.

Whose main objective is to study which alternatives for the construction of social and priority interest housing can be taken into account by the Colombian National
Government. Due to this research, both economic and technical benefits are obtained by implementing the model of environmentally sustainable building construction. In which it is deepened in the subject of the handling of material residues used in the construction, to obtain recycled materials with technical characteristics that allow their reuse in the construction of new buildings, the contribution to the environment diminishing the contamination and emissions of polluting agents to the air.

One of the objectives of the research was to understand the difference between traditional and sustainable construction, in which sustainable construction seeks to meet the needs of energy, water, proper management of materials and be friendly to the environment. We not only take into account the process of construction of a building and leave behind what could happen later, but now we take into account since the design of the building, construction, operation and subsequent demolition.

In the same way [10] I carry out a research on Analysis of sustainable buildings as the best economic, social and environmental alternative for construction in Colombia.

Whose objective is to carry out research on the environmental and social benefits and one of the important objectives of this research is the economic savings, which are obtained with this model of building construction, since this research determined that it is totally viable this new alternative of construction, providing a rational use of natural resources, The economic savings are reflected from the beginning of its execution, where a sustainable building can cost less than one that is built traditionally, where structural, electrical, and mechanical systems can be reduced, also in energy consumption since the expense is reduced by $30 \%$ compared to a traditional building. 
Theoretical basis

The term sustainable building processes includes not only buildings, but also takes into account the environment and the way they are integrated to form cities. Sustainable urban development (sustainable environmental process). It aims to create an urban environment that does not harm the environment, and that generates sufficient urban resources, not only in terms of forms and energy and water efficiency, but also for its functionality, as a better place to live. [11]. It is essential to start relating more to the concept of sustainable environmental processes, due to the great damage we are causing to the environment by re-directing us to make good use of all the resources that nature provides us with.

By means of the traditional construction that has been implemented to date, not taking into account the damage we are causing to future generations and that we still have time to correct these errors, to look at new horizons more feasible for the development of construction that are more friendly to the environment. The rapid growth and development of the industrialized countries have been drastically affecting the environment and they believe that the available resources are unlimited, together with the fact that the impacts we produce on the environment are generally so long term that they are not directly appreciated, making the effects of our development model suffer the future generations. [12].

The construction industry is, without a doubt, a protagonist in the development of societies, since it is directly responsible for the creation of infrastructure for housing, transport, health facilities, among other projects, in which culture and economic growth are generated [13]. Due to the fact that humanity is growing exponentially, the constructions of infrastructure in the same way, since it is one of the fundamental economic pillars of a country and it makes us go towards a better future, nevertheless, we have to keep in mind that if we build without taking into account the damage that we cause to the environment we will be affected in the future, for this reason the civil construction that begins to be executed would be made taking into account all these factors example of them allow to reduce structural, electrical, and mechanical systems, also in the consumption of energy since the cost is reduced in $30 \%$ compared to a traditional building. [14].

The generation of solid waste and pollutants is also a serious environmental problem associated with the construction sector, which is the main generator of greenhouse gases in many countries. These emissions reached 8.6 billion metric tons in 2004, according to the Intergovernmental Panel on Climate Change, a figure that could reach 15.6 billion metric tons by 2030 , if construction continues as it is today. [15] For this and many other reasons that influence the continued deterioration of the ecosystem, it is necessary to address new construction methods to curb accelerated pollution to the environment, such as environmentally sustainable construction in building construction.

\section{Methodology}

The present research project was developed under the modality of the descriptive method and the direct observation, through the investigation it is analyzed how the construction of buildings has been developed, by means of the traditional constructive model and that effects when applying this methodology impart on the environment, and according to this environmental criteria are established that are proposed to satisfy all the problems that are observed when applying this modality of construction, as they are the environmental sustainable processes in construction of buildings. 


\section{2}

Results

1. Sustainable building materials can be considered to be those that are durable and need little maintenance, and can be recycled or recovered.

- Photovoltaic panels: capable of producing electricity from the sunlight that falls on them, which reduces the use of fossil fuels, prevents global warming, is non-polluting, renewable and inexhaustible.

-Wood: these are one of the most sustainable materials, considered to be the material with the least environmental impact in its production, due to the fact that during its life cycle it is capable of eliminating a large amount of $\mathrm{CO} 2$. It has a great insulating capacity that could save between 50 and $60 \%$ in heating and air conditioning.

- Agglomerated cork: is a natural product that has excellent properties in terms of thermal and acoustic insulation and very low conductivity.

- Cellulose fibers or recycled paper: It is composed of sheets of reused newspaper that have been treated with borax salts to give it fireproof, insecticide and anti-fungal properties.

-Polypropylene, polybutylene and polyethylene: These are thermoplastic materials that can be used for heating systems, water pipes and drainage. Their main advantage is that they do not contain chlorine in their composition, so they are not toxic. They are also chemically inert, sterilizable and recyclable.

Thus, in order for a material to be properly sustainable, each of the processes through which it passes must be taken into account, from the extraction of the raw material, the transport necessary at each stage, the processes of transformation of the material, the way in which the material is used, its disposal after its useful life, its capacity to be recycled or reused.

2. This type of construction model increases efficiency in the use of resources, helps to reduce the high rates of energy consumption and the exploitation of natural resources. It brings with it different environmental contributions such as

- Energy saving

- Improves the indoor climate of buildings

- Creation of a healthy and non-toxic environment in the buildings

- A minimum amount of waste and pollution is generated during the construction of a building.

3. Sustainable buildings in comparison to traditional buildings represent in environmental terms a $30 \%$ reduction in energy consumption, $35 \%$ less carbon emissions, $30 \%$ to $50 \%$ less water consumption, excellent use of natural resources and $50 \%$ to $90 \%$ less waste and residues.

Another great difference of this constructive model is the economic profitability that it entails due to the reductions of operation costs $13.6 \%$, the increase of the cost of the building $10.9 \%$, even all these economic reductions are reflected from the initial cost of the construction and less energy consumption that reduces the expense in $30 \%$ compared to the construction of a traditional building. Green buildings built with bioclimatic materials can generate sufficient energy savings compared to conventional constructions.

\section{Discussion}

The results obtained in this project, show that after considering the usefulness and benefits provided by the materials extracted 
from the environment that could be used in the planning and construction process, it has a certain preference with the materials that have a longer life or duration and their longterm maintenance, as photovoltaic panels, wood, agglomerated cork, cellulose fibers or recycled paper, polypropylene, polybutene and polyethylene among others, which with a respective and appropriate process can fulfill their function and provide their respective utility to the construction, likewise after finishing its useful life have that ability to be reused.

With regard to the previous paragraph, it can be said that sustainability will take into account not only the construction in the creation of the environment, but also the effects that this will produce on those who carry it out and on those who will live in them. The growing importance of "sick building syndrome" considerations in office buildings and "environmental sensitivity" in housing construction has led to greater consideration of the effects that building materials have on human health [16].

We can also highlight the benefits that the correct use of these materials offers us and nature itself by reducing the impact of pollution and destruction of the environment, in turn preserving human health, which is a fundamental part of the implementation of sustainable construction techniques, and the great positive impact of reducing the use of electricity, which brings with it a high cost for its use in lighting, air conditioning and heating services, which are very common in buildings; Thus demonstrating in all areas its profitability and both economically and constructively bringing great satisfaction to the construction companies of the city.

\section{Conclusions}

From the present project it could be concluded that there are strategies and techniques that can be implemented in the city of Cúcuta, taking into account the correct and adequate obtaining of materials extracted from nature that can be found in most of the department following guidelines and specifications to carry out this type of environmentally friendly construction.

Similarly, it was possible to identify the benefits that nature gives us by providing us with certain materials that, after being processed, can be the main reason why a change in construction techniques, in the use and processing of construction materials, and in customs in favour of the environment, arrives in the city of Cúcuta, thus making the inhabitants feel a sense of belonging to the planet [17]. Consequently, it is important to highlight the economic relief that the construction companies of the city of Cúcuta will have with respect to the importation of materials and the expenses generated by these materials after they are implemented in the buildings while they are in use, since they will have a long useful life, having as a main advantage that in their respective moment when the building fulfills its permissible life cycle, these can be recycled and regenerated.

\section{Reference}

[1] L. X. Hernandez Vélez, "Master Plan Contribution Evaluation in the construction of urban resilience and sustainability in the city of Bogot", Respuestas, vol. 23, n. ${ }^{\circ}$ 1, pp. 72-77, abr. 2018

[2] R. Lanting, "Sustainable construction in the Netherlands", TNO BUILDING AND CONSTRUCTION RESEARCH. [En línea]. Disponible en:https://www.irbnet.de/daten/ iconda/CIB13589.pdf

[3]A. Sarabia-Guarin, J. Sánchez-Molina, y J. C. Leyva-Díaz, "Uso de nutrientes tecnológicos como materia prima en la fabricación de 


\section{4}

materiales de construcción en el paradigma de la economía circular", Respuestas, vol. 22, no. ${ }^{\circ}$ 1, pp. 6 - 16, ene. 2017

[4] A. Barreto, "Así son las nuevas oficinas de Apple, el edificio más caro de Estados Unidos", La Vanguardia, 2017. [En Línea]. Disponible en: https:/www.lavanguardia.com/ tecnologia/20171227/433892571002/applepark.html

[5] E. Montoya, "Prácticas sostenibles en la construcción de edificaciones", trabajo de grado, Pontificia Universidad Católica del Perú, 2014.

[6] P. Zarta Ávila, "LA SUSTENTABILIDAD O SOSTENIBILIDAD: UN CONCEPTO PODEROSO PARA LA HUMANIDAD”, Tabula Rasa, no. 28, 2018

[7] Argos, "Tendencias de construcción sostenible en Colombia 2019”, 2018. [En línea]. Disponible en: https://colombia.argos.co/Acerca-de-Argos/ Sostenibilidad/tendencias-de-construccionsostenible-en-colombia-2019

[8] M. Salazar, "Sostenibilidad edificios en zona fronteriza Cúcuta” Cúcuta, 2019

[9] J.M. Susunaga Monroy, “Construcción sostenible, una alternativa para la edificacion de viviendas de interes social y prioritario", Universidad Católica de Colombia, 2014

[10] N.P Malaver Jaramillo y N.F Ortiz Esguerra, "Análisis de las edificaciones sustentables como la mejor alternativa económica, social y ambiental para la construccion en Colombia", Universidad La Gran Colombia, 2018

[11] A. Ramires, "La construcción sostenible", Construccion verde España, 2015

[12]H. Acevedo Agudelo, A. VásquezHernández, D.
Ramírez Cardona, "Sostenibilidad: Actualidad y necesidad en el sector de la construcción en Colombia, Gestión y Ambiente, vol. 15, no. 1, pp 105-118, ene. 2012

[13] L.C Pinilla Vera, "Construcción sostenible en Colombia" trabajo de grado, Universidad de Los Andes, Bogotá, Colombia, 2010

[14] R. Estévez, "Beneficio del diseño sostenible en la edificacion", Eco inteligencia, 2015. [En línea]. Disponible en: https://www. ecointeligencia.com/2015/09/beneficiosdiseno-sostenible-edificacion/

[15] J.M Susunaga Monroy, "Construcción sostenible, una alternativa para la edificación de viviendas de interés social y prioritario", trabajo de grado, Universidad Católica de Colombia, 2014.

[16] P. Alavedra, J. Domínguez y J. Serra "La construcción sostenible. "El estado de la cuestión", [En línea]. Disponible en: http:// habitat.aq.upm.es/boletin/n4/apala.html

[17] M.S. Borsani, "Materiales ecológicos: estrategias al alcance y aplicación de los materiales ecológicos como generadores de habitats urbanos sostenibles", 2011. [En línea]. Disponible en: https://upcommons.upc.edu/ bitstream/handle/2099.1/13759/Borsani,\%20 Mar\%C3\%ADa\%20Silvia.pdf 